\title{
Evidence for a Mouse Mesangial Cell-derived Factor That Stimulates Lymphocyte Proliferation
}

\author{
E. Paul MacCarthy, Angela Hsu, Yuet M. Ooi, and Boon S. Ooi \\ Division of Nephrology and Hypertension Program, Department of Internal Medicine, University of \\ Cincinnati Medical Center, Cincinnati, Ohio 45267
}

\begin{abstract}
The functions of the glomerular mesangium are served by at least two populations of cells-a cell bearing microfilaments that regulates blood flow, and a phagocytic cell bearing Ia determinants and Fc receptors. We provide evidence that mouse mesangial cells (bearing microfilaments) produce a factor(s) that stimulates spleen cell proliferation. The factor(s) appears to act via monocytes/macrophages, since its stimulatory activity is abrogated by prior depletion of the responding mononuclear cell population of monocytes/macrophages. Confirmation of its action on macrophages was documented by experiments that showed that medium from macrophages incubated with mesangial cell supernatant contained greater amounts of a factor that stimulated $\left[{ }^{3} \mathbf{H}\right]$ thymidine uptake by macrophage-depleted spleen cell populations. By the cothymocyte proliferation assay, it could be shown that mesangial cell supernatant induced splenic macrophage production of interleukin-1-like activity. Preliminary characterization reveals the factor to have a molecular weight $>100,000$. Thus, a novel function is delineated for this mesangial cell type that appears capable of modulating the local immune response by providing an amplification signal.
\end{abstract}

\section{Introduction}

The functions of the glomerular mesangium include the regulation of glomerular blood flow and the uptake of macromolecules (1). These two functions are subserved by at least two populations of cells. One cell type bears microfilaments, has receptors for angiotensin II and vasopressin $(2,3)$, elaborates products of arachidonic acid metabolism $(4,5)$, synthesizes fibronectin (6), and produces proteolytic enzymes (7). The other cell type possesses Ia antigens, Fc receptors, and phagocytic capacity, presents antigens and has many of the characteristics of monocytes/macrophages (8). We report in this communication a novel function of the first cell type, the contractile cell bearing microfilaments, namely that it elaborates an immunoregulatory factor that stimulates spleen cell proliferation, and appears to do so by its action on the monocyte/ macrophage, since depletion of the responding cell population of monocytes/macrophages removes its stimulatory activity.

This paper was presented in part at the National Meeting of the American Federation of Clinical Research, Washington, D.C., 1984. Address reprint requests to Dr. B. S. Ooi.

Received for publication 26 January 1984 and in revised form 1 April 1985.

J. Clin. Invest.

(c) The American Society for Clinical Investigation, Inc.

0021-9738/85/08/0426/05 $\$ 1.00$

Volume 76, August 1985, 426-430
Furthermore, it can be shown that the mesangial cell-derived factor induces macrophage production of interleukin-1-like activity.

\section{Methods}

Cultivation of mouse mesangial cells and preparation of mesangial cell supernatant. The procedures for cultivation and the characteristics of mouse mesangial cells have been previously reported in detail (9). In brief, glomeruli were isolated from male C57BL/6J mice (Jackson Laboratories, Bar Harbor, ME) 12-20-wk-old by a sieving technique (10). Glomeruli were plated onto 30-ml tissue culture flasks (Corning Labware, Corning Glass Works, Corning, NY) that contained modified Eagle's medium (MEM;' Gibco Laboratories, Grand Island, NY) supplemented with $20 \%$ heat-inactivated fetal calf serum (FCS), Lglutamine $(2 \mathrm{mM})$, penicillin $(100 \mathrm{U} / \mathrm{ml})$, and streptomycin $(100 \mu \mathrm{g} /$ $\mathrm{ml}$ ) in a $37^{\circ} \mathrm{C}$ humidified $5 \% \mathrm{CO}_{2}$ incubator. This medium will be designated complete MEM. Cellular outgrowths were observed 10-14 $\mathrm{d}$ after seeding. Cultures were fed biweekly and transferred at confluence. For preparation of mesangial cell supernatants, aliquots of mesangial cells $\left(0.5-1 \times 10^{7}\right.$ cells) were grown in $20 \mathrm{ml}$ complete MEM to confluence and supernatant harvested. Preliminary experiments revealed that the immunoregulatory factor was detectable by $24 \mathrm{~h}$ culture. Initial studies that tested supernatants from cultures of mesangial cells grown in MEM with and without FCS showed that the immunostimulatory activity of supernatants of mesangial cells cultured in MEM containing FCS was more potent than that derived from serum-less media and, as such, experiments were performed using such material containing FCS. Cell debris was spun down, supernatant passed through a $0.22-\mu \mathrm{M}$ filter (Millipore Corp., Bedford, MA) and stored at $-70^{\circ} \mathrm{C}$ in aliquots before use. Control complete MEM was treated in an identical fashion except for the growth of mesangial cells. Media were screened for endotoxin by the Limulus assay (Pyrotest; Difco Laboratories, Detroit, MI) using the Pyrotest kit according to the manufacturer's recommendations. In brief, the test was conducted by adding $0.1 \mathrm{ml}$ of Pyrotest (Limulus Amebocyte Lysate) (Difco Laboratories) to $0.1 \mathrm{ml}$ of test solution, mixing the solutions and incubating for $1 \mathrm{~h}$ in a $37^{\circ} \mathrm{C}$ waterbath. The presence of endotoxin was indicated by the formation of a firm gel clot that remained intact when inverted through $180^{\circ}$. Positive and negative controls were incorporated in the runs, and the test was sensitive to $100 \mathrm{pg}$ endotoxin/ml. Media (control and mesangial cell supernatant) were screened for endotoxin, and batches with no detectable endotoxin were used for the studies. Limited studies (data not shown) were also done in which the spleen cells of $\mathrm{C} 3 \mathrm{H} / \mathrm{HeJ}$ mice (endotoxin unresponsive) could be shown to respond to mesangial cell supernatant in a dose-dependent fashion. The results of these studies provided further confirmation that endotoxin was not responsible for the immunostimulatory effect seen. As a tissue control, supernatants from 3T3 cells (American Type Culture Collection, Rockville, MD) were harvested and tested for immunoregulatory activity.

To determine if protein synthesis was required for the generation of immunostimulatory activity in mesangial cell supernatant, mesangial

1. Abbreviations used in this paper: FCS, fetal calf serum; MEM, modified Eagle's medium; PHA, phytohemagglutinin. 
cell cultures were pretreated with varying doses of cycloheximide for $24 \mathrm{~h}$, cells thoroughly washed, and replaced with fresh MEM (time 0). Thereafter, media was collected at varying time intervals and tested for immunoregulatory activity at $90 \%$ concentration. A parallel series (control cultures) of mesangial cell cultures was established without cycloheximide treatment. Values for $\left[{ }^{3} \mathrm{H}\right]$ thymidine uptake of spleen cells incubated with supernatant from cycloheximide-treated mesangial cell cultures (experimental values) and of $\left[{ }^{3} \mathrm{H}\right]$ thymidine uptake of spleen cells incubated with supernatant from untreated mesangial cell cultures (control values) were obtained. Percentage of stimulatory activity was given by: (experimental value)/(control value) $\times 100 \%$.

The characteristics of the mouse mesangial cells have been described previously in detail (9). Cells were used after the fifth passage when they were apparently homogenous (as assessed by phase contrast and light microscopy and by their staining characteristics), and also to exclude the possibility of contamination by blood cells. Thus, $>90 \%$ of the cells reacted by indirect immunofluorescence with anti-mouse fibronectin (gift of Dr. E. Engvall, La Jolla Cancer Research Foundation, La Jolla, CA) and with monoclonal antibody to smooth muscle actin (prepared against chicken gizzard and not reactive with fibroblasts (gift of Dr. J. Lessard, Cincinnati Children's Hospital Research Foundation, Cincinnati, $\mathrm{OH}$ ). Contamination with monocytes and with lymphocytes was excluded by absence of reactivity with anti-Mac 1 (gift of Dr. T. Springer, Harvard Medical School, Boston, MA), anti-Thy 1,2, (Litton Bionetics, Kensington, MD), and monoclonal anti-la (supernatant of clone M5/114. ${ }^{15.2}$ American Type Culture Collection, Rockville, MD) as assessed by indirect immunofluorescence. None of the cells could be shown to have $\mathrm{Fc}$ or $\mathrm{C} 3 \mathrm{~b}$ receptors. They have the ultrastructural characteristics of the mesangial cells reported by Ausiello et al. (2). The cells have an oval nucleus, abundant microfilaments parallel to the long axis of the plasma membrane, and exhibit surface dense patches. The cells were not sensitive to the addition of the aminonucleoside of puromycin, and their growth characteristics were unchanged in D-valine substituted medium, which further indicated that they were not fibroblasts. By cell labeling techniques, they could be shown to synthesize fibronectin (6).

Assay for mouse spleen cell uptake of $\left[{ }^{3} \mathrm{H}\right]$ thymidine. Mouse spleen cell suspensions, adjusted to a concentration of $1 \times 10^{7} \mathrm{cells} / \mathrm{ml}$ in complete MEM, were dispensed to give $2 \times 10^{5}$ cells to each well of flat-bottomed tissue culture plates (Microtest II, Falcon Labware, Becton-Dickinson \& Co., Oxnard, CA). The final volume in each cell was $200 \mu$, which consisted of varying concentrations of mesangial cell supernatant and control media. All experiments were done in triplicate or more. Cells were incubated with mesangial cell supernatant or with control media for varying time periods and then pulsed with $1 \mu \mathrm{Ci}$ of $\left[{ }^{3} \mathrm{H}\right]$ thymidine $(20 \mu \mathrm{Ci} / \mathrm{mmol}$, New England Nuclear) for 16 h. The cells were harvested onto glass filter fibers and washed with distilled water using a semi-automatic cell harvester (Titertek Cell Harvester, Flow Laboratories, Inc., Rockville, MD). Filter disks were punched out and transferred to scintillation vials containing Aquasol2 (New England Nuclear) and counted in a LS-7000 scintillation counter (Beckman Instrument Inc., Fuller-ton, CA).

For monocyte/macrophage depletion experiments, identical procedures were used except that aliquots of splenic cells were depleted of monocytes/macrophages by passage through a Sephadex G-10 column as described in detail by Ly and Mishell (11). Depleted cells were shown to have $1 \%$ monocytes/macrophages as assessed by ingestion of sensitized sheep erythrocytes.

Since experiments showed that the stimulatory activity of the mesangial cell supernatant was dependent on the presence of monocytes/ macrophages in the responding cell population, experiments were directed towards confirming this effect. Splenic macrophages from resident mice were obtained by adherence, plating $4 \times 10^{7}$ cells in 2 $\mathrm{ml}$ complete MEM onto a $60 \times 15-\mathrm{mm}$ plastic petri dish, and incubating for $90 \mathrm{~min}$ at $37^{\circ} \mathrm{C}$ in a $5 \% \mathrm{CO}_{2}$ incubator. Nonadherent cells were removed by four successive washes with MEM; $\mathrm{T}$ cells were eliminated by treatment with anti-Thy 1,2 antiserum (Litton Bionetics, Charleston, SC) and rabbit complement (Accurate Scientific and Chemical Co.,
Westbury, NY). In separate experiments, the resultant populations could be shown to be $\sim 95 \%$ monocytes/macrophages as assessed by ingestion of sensitized sheep erythrocytes. $T$ cell contamination as assessed by immunofluorescence using anti-Thy 1,2 antiserum was $\sim 1 \%$. Macrophages were incubated with either $90 \%$ mesangial cell supernatant or control MEM for $24 \mathrm{~h}$. Supernatant was then harvested, cellular debris spun down, dialyzed against media, millipored, and stored at $-70^{\circ} \mathrm{C}$ until use. The effect of the dialyzed conditioned media on $\left[{ }^{3} \mathrm{H}\right]$ thymidine uptake of macrophage-depleted spleen cells was examined; concurrent experiments were done testing dialyzed supernatants of macrophages incubated with control MEM; as an added control, mesangial cell supernatant was tested on the macrophagedepleted spleen cell cultures to ensure that there was no direct stimulatory effect of the supernatant on its lymphocyte cultures.

To determine if mesangial cell supernatant induced the production of interleukin-1-like activity, the $\mathrm{C} 3 \mathrm{H}-\mathrm{HeJ}$ mouse co-thymocyte proliferation assay was used (12). Dialyzed supernatants were obtained as described above from either untreated macrophages or macrophages incubated with mesangial cell supernatant ( $90 \%$ concentration). Varying aliquots of supernatant were added to $1 \times 10^{6}$ thymocytes (final volume $250 \mu \mathrm{l}$ ) with either phytohemagglutinin (PHA) or without PHA (1 $\mu \mathrm{g} / \mathrm{ml}$; Gibco Laboratories) for $72 \mathrm{~h}$. An aliquot of $1 \mu \mathrm{Ci}$ $\left[{ }^{3} \mathrm{H}\right]$ thymidine was added for the final $16 \mathrm{~h}$ of culture and $\left[{ }^{3} \mathrm{H}\right]$ thymidine incorporation was measured as described previously. Experiments were also done testing mesangial cell supernatant directly (without incubation with macrophages) to determine if it had interleukin-1-like activity.

Preliminary characterization. Three fractions were obtained by ultrafiltration using Amicon membranes UM-10 and XM-100 (Amicon Corp., Lexington, MA) with molecular cut-offs of 10,000 and 100,000 mol wt, respectively. Fractions were used reconstituted to $50 \%$ of original volume (except for fraction $<10,000 \mathrm{~mol} \mathrm{wt}$ ) and used at a concentration of $90 \%$ when tested on spleen cultures incubated with these for $96 \mathrm{~h}$. Control media were fractionated in an identical fashion and tested in parallel with fractions of conditioned media.

The effect of heat and of trypsin treatment on the immunostimulatory properties of mesangial cell supernatant was also examined. In the case of trypsin, the supernatant was incubated with concentrations of $4 \times 10^{-6} \mathrm{M}$ and $4 \times 10^{-7} \mathrm{M}$ trypsin (bovine pancreas, Sigma Chemical Co., St. Louis, MO). Controls treating spleen cells with the same concentrations of trypsin were also done and were found to have no significant effect on spleen cell uptake of $\left[{ }^{3} \mathrm{H}\right]$ thymidine.

\section{Results}

The temporal kinetics of spleen cell uptake of $\left[{ }^{3} \mathrm{H}\right]$ thymidine after incubation with mesangial cell supernatants for varying intervals are shown in Fig. 1. Stimulation of spleen cell $\left[{ }^{3} \mathrm{H}\right]$ thymidine uptake by mesangial cell supernatant was evident by $72 \mathrm{~h}$. Fig. 2 shows the dose-response curve of spleen cell $\left[{ }^{3} \mathrm{H}\right]$ thymidine uptake with varying amounts of mesangial cell supernatant. Enhanced spleen cell $\left[{ }^{3} \mathrm{H}\right]$ thymidine uptake was demonstrated with increasing amounts of supernatant. Different batches of supernatant exhibited varying potencies.

A comparison of the immunostimulatory properties of supernatant from $3 \mathrm{~T} 3$ cell cultures and mesangial cell cultures are given in Fig. 3. Supernatant from 3T3 cell cultures did not exhibit any immunostimulatory activity.

To determine if protein synthesis was required for the generation of immunostimulatory activity in the supernatants of mesangial cell cultures, the cells were pretreated with varying doses of cycloheximide, washed, and replaced with fresh media. Aliquots of supernatants were then obtained at varying time intervals and assessed for immunostimulatory activity. The results are shown in Fig. 4 . When the cells were pretreated with $10 \mu \mathrm{g} / \mathrm{ml}$ cycloheximide, the resultant super- 


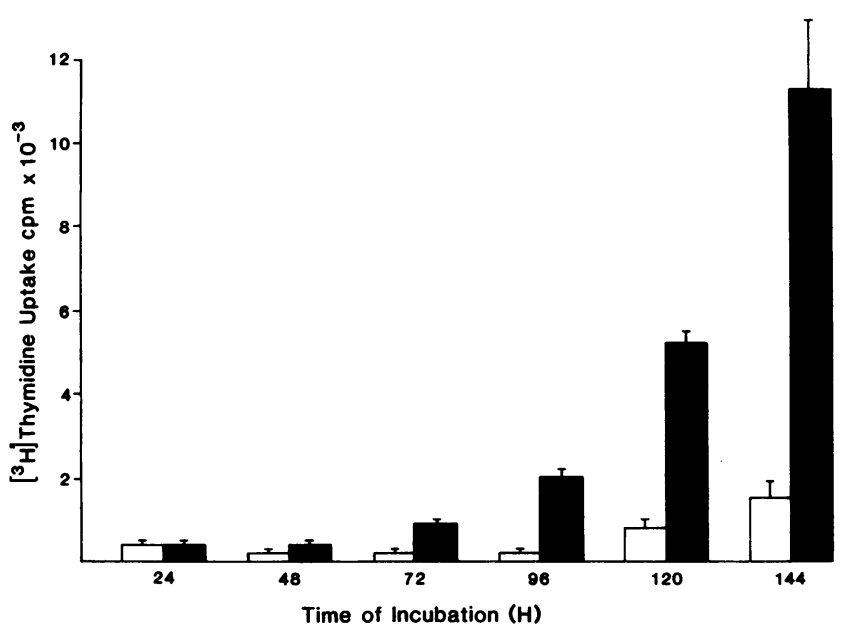

Figure 1. Temporal kinetics of $\left[{ }^{3} \mathrm{H}\right]$ thymidine uptake by spleen cells incubated with mesangial cell supernatants. An aliquot of $2 \times 10^{5}$ spleen cells was incubated with $90 \%$ concentration of mesangial cell supernatant or with control media for varying periods, and $\left[{ }^{3} \mathrm{H}\right]$ thymidine uptake was measured. The results are the mean $\pm \mathrm{SE}$ of triplicate cultures. $a$, Experimental culture; $\square$, control culture.

natant exhibited only $7.8 \%$ stimulatory activity at $24 \mathrm{~h}$, but had recovered to $92.4 \%$ at $48 \mathrm{~h}$, becoming normal thereafter. By comparison, when mesangial cells were pretreated with 50 $\mu \mathrm{g} / \mathrm{ml}$ cycloheximide, there was very poor recovery of stimulatory activity of supernatants obtained from these cultures, which were incomplete at $96 \mathrm{~h}$.

To examine the cellular mechanism by which mesangial cell supernatant obtained this stimulatory effect, experiments were done using fractionated cell populations. The results, shown in Fig. 2, demonstrate that with monocyte-macrophage depletion by passage of spleen cells through a Sephadex G-10 column, the stimulatory activity of mesangial cell supernatant was entirely removed, indicating that it exerted its effect via monocytes/macrophages.

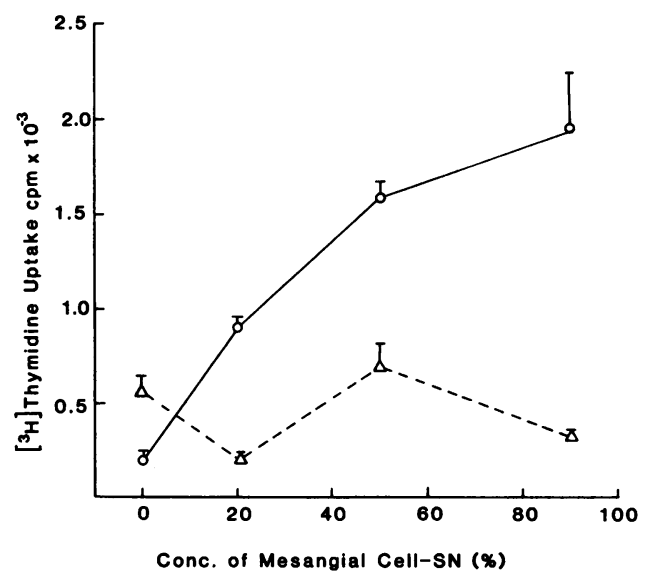

Figure 2. Effect of varying concentrations of mesangial cell supernatant (SN) on spleen cell $\left[{ }^{3} \mathrm{H}\right]$ thymidine uptake under varying conditions. An aliquot of $2 \times 10^{5}$ spleen cells was incubated with varying concentrations of mesangial cell SN for $96 \mathrm{~h}$ and the amount of $\left[{ }^{3} \mathrm{H}\right]$ thymidine uptake was measured. Spleen cells were either used untreated $(0)$ or monocyte/macrophage depleted $(\Delta)$. The results are the mean \pm SE of triplicate cultures.

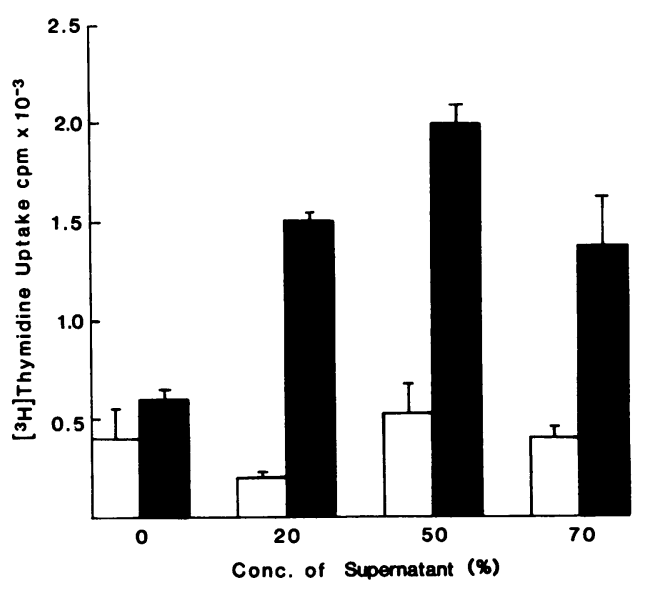

Figure 3. Comparison of effect of supernatants from 3T3 cell cultures and mesangial cell cultures on spleen cell $\left[{ }^{3} \mathrm{H}\right]$ thymidine uptake. Protocols are as in Fig. 2. Note that supernatants from 3T3 cell cultures have no stimulatory effect on spleen cell $\left[{ }^{3} \mathrm{H}\right]$ thymidine incorporation. Results are mean $\pm \mathrm{SE}$ of triplicate cultures for mesangial cell supernatants $(\square)$ and of six cultures for 3T3 cell supernatants (口).

The effect obtained on macrophage-depleted spleen cells $\left[{ }^{3} \mathrm{H}\right]$ thymidine uptake with medium harvested from macrophages incubated with mesangial cell supernatant is shown in Fig. 5. It is evident that the medium of such macrophage cultures contained greater amounts of a substance that stimulated lymphocyte $\left[{ }^{3} \mathrm{H}\right]$ thymidine uptake, compared with supernatant of macrophages cultured with control medium alone. Mesangial cell supernatant by itself had no direct effect on $\left[{ }^{3} \mathrm{H}\right]$ thymidine uptake of these lymphocyte cultures.

The results for the assay for interleukin-1-like activity in the supernatants of macrophages incubated with control media and with mesangial cell supernatant are shown in Fig. 6. Mesangial cell supernatant by itself had no significant effect on thymocyte proliferation (with and without PHA, data not

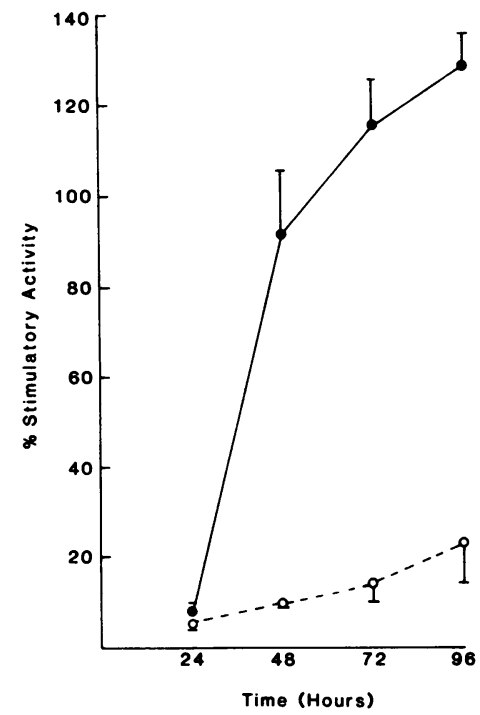

Figure 4. Effect of pretreatment of mesangial cells with cycloheximide on the generation of immunostimulatory activity in subsequent supernatants of cell cultures. Protocols for experiments and calculation of percentage of stimulatory capacity are given in Methods. When mesangial cells were treated with 10 $\mu \mathrm{g} / \mathrm{ml}$ cycloheximide (๑), supernatants showed $7.8 \%$ stimulatory capacity at 24 $\mathrm{h}, \mathbf{9 2 . 4 \%}$ at $48 \mathrm{~h}$, and became normal thereafter. With treatment of mesangial cells with $50 \mu \mathrm{g} / \mathrm{ml}$ cycloheximide (O), recovery of stimulatory capacity was very poor and incomplete at $96 \mathrm{~h}$. Values represent mean $\pm \mathrm{SE}$ of six cultures. 


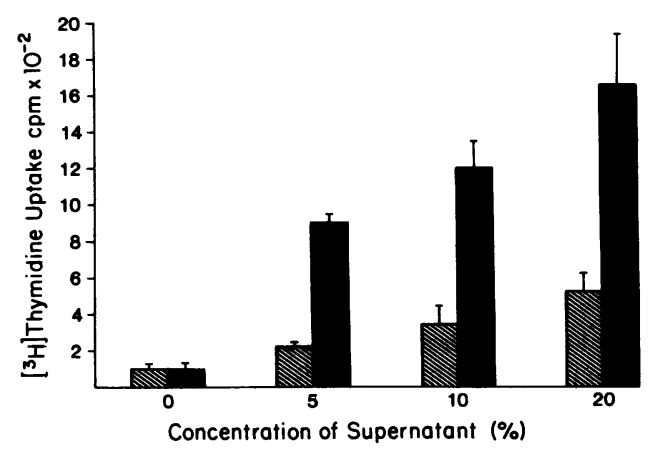

Figure 5. Effect of various supernatants $(\mathrm{SN})$ on $\left[{ }^{3} \mathrm{H}\right]$ thymidine uptake of macrophage-depleted spleen cells. SN was derived from macrophages cultured with either $90 \%$ mesangial cell SN or with control MEM done for $24 \mathrm{~h}$, and tested at varying concentrations on $\left[{ }^{3} \mathrm{H}\right]$ thymidine uptake of aliquots of $2 \times 10^{5}$ macrophage-depleted spleen cells. Mesangial cell SN by itself had no effect on $\left[{ }^{3} \mathrm{H}\right]$ thymidine uptake of lymphocyte cultures (data not shown). The results are the mean $\pm S E$ of quadruplicate cultures. 1 , Macrophage$\mathrm{SN} ; \mathrm{a}, \mathrm{SN}$ of macrophages incubated with mesangial cell-SN.

shown). When supernatants from macrophages were tested, it was evident that in the presence of PHA, thymocytes proliferated more readily in response to supernatants from macrophages conditioned with mesangial cell supernatant compared with control macrophage supernatants. (Without PHA, there was no significant effect of both types of supernatant on thymocyte proliferation; data not shown.)

The results of studies on the preliminary characterization of the immunoregulatory factor(s) are shown in Fig. 7. Stimulatory activity was found in the $>100,000-\mathrm{mol}$ wt fractions.

The results of treatment of mesangial cell supernatant with

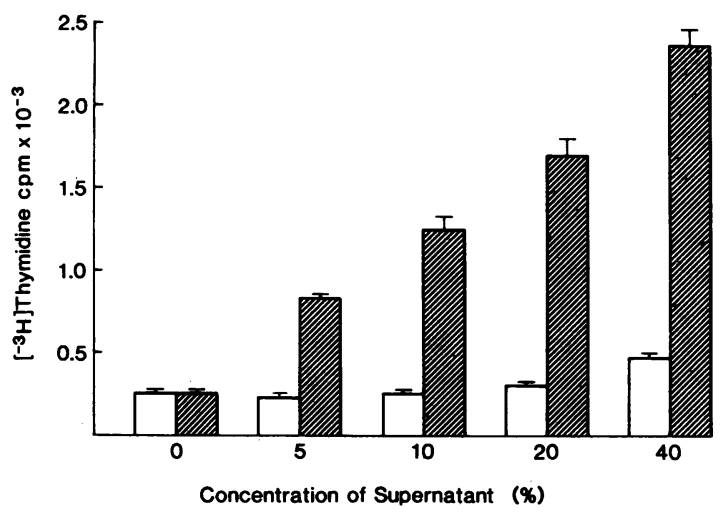

Figure 6. Assay for interleukin-1-like activity in the supernatants (SN) of untreated macrophages and macrophages incubated with $90 \%$ mesangial cell $\mathrm{SN}$ by the cothymocyte proliferation assay. An aliquot of $1 \times 10^{6}$ thymocytes was incubated with PHA $(1 \mu \mathrm{g} / \mathrm{ml})$ and varying concentrations of $\mathrm{SN}$ derived from either macrophages incubated with control MEM (control cultures) or mesangial cell SN (experimental cultures). At the end of $72 \mathrm{~h}$ incubation, the cells were harvested after having been pulsed with $\left[{ }^{3} \mathrm{H}\right]$ thymidine in the last 16 $h$ of culture. Mean $\pm S E\left[{ }^{3} \mathrm{H}\right]$ thymidine uptake of control cultures was $77 \pm 3 \mathrm{cpm}$, with PHA $233 \pm 17 \mathrm{cpm}$. Mesangial cell SN by itself (with and without PHA), and macrophage SNs without PHA had no significant stimulatory effect on thymocyte uptake of $\left[{ }^{3} \mathrm{H}\right]$ thymidine (data not shown). The values represent mean \pm SE of six cultures. $\square$, Macrophage-SN; 1, SN of macrophages incubated with mesangial cell-SN.

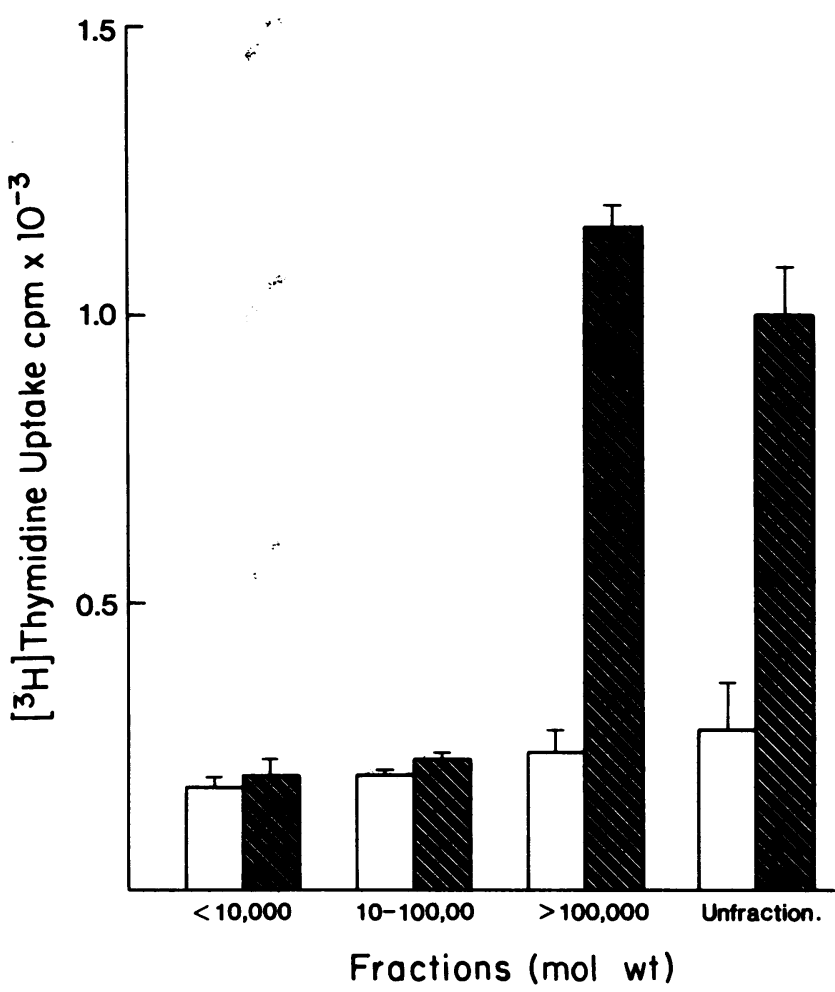

Figure 7. Preliminary characterization of mesangial cell supernatant. Three fractions $<10,000,10,000-100,000$, and $>100,000 \mathrm{~mol}$ wt were prepared by ultrafiltration through Amicon membranes UM-10 and XM-100 (see Methods). Fractions were used at a concentration of $90 \%$ and tested with $2 \times 10^{5}$ spleen cells incubated with them for $96 \mathrm{~h}$. The results show mean \pm SE of triplicate experiments. Note that the $>100,000$-mol wt fraction exhibited stimulatory activity. $\square$, Control; experimental.

heat and trypsin are given in Table I. Heating at $100^{\circ} \mathrm{C}$ for 30 min completely destroyed the immunostimulatory activity of mesangial cell supernatant. The substance(s) in mesangial cell supernatant was resistant to trypsin digestion.

\section{Discussion}

The current data provide evidence that mesangial cells bearing microfilaments produce a factor that stimulates spleen cell proliferation. It appears to exert this effect by its actions on the monocyte/macrophage, since depletion of this cell type from the responding cell population abrogates its activity. Further information of this cellular mechanism of action was provided by experiments showing that supernatants of cultures of macrophages incubated with mesangial cell supernatant

Table I. Effect of Heat and Trypsin Treatment on Immunostimulatory Activity of Mesangial Cell Supernatants

\begin{tabular}{lc}
\hline Treatment & Activity remaining \\
\hline & $\%$ \\
$56^{\circ} \mathrm{C} \times 30 \mathrm{~min}$ & $>95$ \\
$100^{\circ} \mathrm{C} \times 10 \mathrm{~min}$ & 29 \\
$100^{\circ} \mathrm{C} \times 30 \mathrm{~min}$ & 0 \\
Trypsin, $4 \times 10^{-6} \mathrm{M}$ & $>95$ \\
Trypsin, $4 \times 10^{-7} \mathrm{M}$ & $>95$ \\
\hline
\end{tabular}


contain greater amounts of a substance that stimulates lymphocyte proliferation (compared with control macrophage supernatant). Furthermore, it was possible to demonstrate that when mesangial cell supernatants were incubated with macrophages, they induced the production of interleukin-1-like activity as assessed by the cothymocyte proliferation assay. The biochemical identity of the substance as interleukin-1 remains to be defined. A number of immunoregulatory ligands have been produced by the macrophage (13). Among these are interleukin-1, which has immunostimulatory properties, and other substances such as the prostaglandins and the oxygen-derived products that are immunosuppressive. Interleukin-1 has been extremely well characterized $(13,14)$, has been shown to have a molecular weight of 13,000-16,000, exhibits charge heterogeneity, and has important effects on the functions of lymphocytes and other cell types such as the fibroblast $(13,14)$. In terms of immune function, it has been shown to stimulate thymocyte proliferation, induce the production of interleukin-2 by $\mathrm{T}$ lymphocytes (14), and most recently has been shown to stimulate $B$ cells (15). A recent investigation (16) has reported that rat mesangial cells directly elaborate a substance resembling interleukin-1. The factor in our mouse mesangial cell-cultured supernatants is not interleukin-1 as determined from its molecular size and by the cellular locus of its action.

The significance of the present findings relates to the regulation of the local immune response in the glomerulus during nephritis. There is now abundant evidence that in nephritis, there is infiltration of the glomerulus with mononuclear cells, which are predominantly monocytes, but which also contain lymphocytes (17-19). There is evidence that mononuclear cell products exert an effect on mesangial cell proliferation. The results presented here suggest that this interaction may be bidirectional, that mesângial cells may in turn regulate the physiology of the infiltrating mononuclear cells. This is especially important in nephritis, since mesangial hypercellularity usually occurs in this pathologic condition, and if the proliferating mesangial cell produces more of this stimulatory factor it will result in an amplification of the local immune response. In another context, it would appear that the two cell types found in the mesangium, the cell-bearing microfilaments and the Ia-positive phagocytic cell, function complementarily in the modulation of the local immune response. Thus, the Ia-bearing cell acts to present antigen while the contractile cell delivers an amplification signal. Finally, in view of the fact that the immunostimulatory factor described by us acts on monocytes/macrophages, it may be reasonably speculated that one of its cellular loci of activity may be the mesangial Ia-positive phagocytic cell because of the similarities of this cell to the bone marrow-derived monocyte series.

\section{Acknowledgments}

The excellent secretarial assistance of Mary Grannen and Violet Henry is acknowledged. We wish to thank Drs. E. Engvall, T. Springer, and J. Lessard for their generous gifts of antisera.

This study was supported in part by National Institutes of Health grants AM 34628 and AM 17196.

\section{References}

1. Michael, A. F., W. F. Keane, L. Raij, R. L. Vernier, and S. M. Mauer. 1980. The glomerular mesangium. Kidney Int. 17:141-154.

2. Ausiello, D. A., J. I. Kreisberg, C. Roy, and M. J. Karnovsky. 1980. Contraction of cultured rat glomerular cells of apparent mesangial origin after stimulation with angiotensin II and arginine vasopressin. J. Clin. Invest. 15:754-760.

3. Foidart, J., J. Sraer, F. Delarue, P. Mahieu, and R. Ardaillou. 1980. Evidence for mesangial glomerular receptors for angiotensin II linked to mesangial cell contractility. FEBS (Fed. Eur. Biochem. Soc.) Lett. 121:333-339.

4. Sraer, J., J. Foidart, D. Chansel, P. Mahieu, B. Kouznetzova, and R. Ardaillou. 1979. Prostaglandin synthesis by mesangial and glomerular cultured cells. FEBS (Fed. Eur. Biochem. Soc.) Lett. 104: 420-424.

5. Kreisberg, J. I., M. J. Karnovsky, and L. Levine. 1982. Prostaglandin production by homogeneous cultures of rat glomerular epithelial and mesangial cells. Kidney Int. 22:355-359.

6. Ooi, Y. M., M. A. Weiss, and B. S. Ooi. 1983. Modulation of mesangial cell fibronectin synthesis by macrophage supernatants. Kidney Int. 23:188. (Abstr.)

7. Lovett, D. H., R. B. Sterzel, M. Kashgarian, and J. L. Ryan. 1983. Neutral proteinase activity produced in vitro by cells of the glomerular mesangium. Kidney Int. 23:342-349.

8. Schreiner, G. F., J. M. Kiely, R. S. Cotran, and E. Unanue. 1981. Characterization of resident glomerular cells in the rat expressing Ia determinants and manifesting genetically restricted interactions with lymphocytes. J. Clin. Invest. 68:920-931.

9. Ooi, Y. M., M. A. Weiss, A. Hsu, and B. S. Ooi. 1983. Mechanisms of suppression of mouse mesangial cell proliferation by macrophage supernatant. J. Immunol. 130:1790-1795.

10. Barcelli, U., R. Rademacher, Y. M. Ooi, and B. S. Ooi. 1981. Modification of glomerular immune complex deposition in mice by activation of the reticuloendothelial system. J. Clin. Invest. 67:20-27.

11. Ly, I. A., and R. I. Mishell. 1974. Separation of mouse spleen cells by passage through columns of Sephadex G-10. J. Immunol. Methods. 5:239-247.

12. Mizel, S. B. 1981. Production and quantitation of lymphocyte activating factor (interleukin 1). In Manual of Macrophage Methodology. H. B. Herscowitz, H. T. Holdegg, J. A. Bellanti, and A. Ghaffar, editors. Marcel Dekker, NY. 407-414.

13. Unanue, E. R. 1981. The regulatory role of macrophages in antigenic stimulation. Part two: Symbiotic relationship between lymphocytes and macrophages. Adv. Immunol. 31:1-36.

14. Mizel, S. B. 1982. Interleukin I and T cell activation. Immunol. Rev. 63:51-72.

15. Booth, R. J., and J. D. Watson. 1984. Interleukin I induces proliferation in two distinct $B$ cell subpopulations responsive to two different murine B cell growth factors. J. Immunol. 133:1346-1349.

16. Lovett, D. H., J. L. Ryan, and R. B. Sterzel. 1983. A thymocyteactivity factor derived from glomerular mesangial cells. J. Immunol. 130:1796-1808.

17. Schreiner, G. F., R. S. Cotran, V. Pardo, and U. Unanue. 1979. A mononuclear cell component in experimental immunologic glomerulonephritis. J. Exp. Med. 147:369-384.

18. Hunsicker, L. G., T. P. Shearer, S. B. Plattner, and D. Weisenburger. 1979. The role of monocytes in serum sickness nephritis. J. Exp. Med. 150:413-425.

19. Holdworth, S. R., T. J. Neale, and C. B. Wilson. 1981. Abrogation of macrophage-dependent injury in experimental glomerulonephritis in the rabbit: use of an antimacrophage serum. J. Clin. Invest. 68:686-698. 